\section{The Salinity Tolerance of Seeded-type Common Bermudagrass Cultivars and Experimental Selections}

\author{
Mingying Xiang ${ }^{1}$, Justin Q. Moss ${ }^{2,4}$, Dennis L. Martin², and \\ Yanqi $\mathrm{Wu}^{3}$
}

AdDITIONAL INDEX wORDs. Cynodon dactylon, dark green color index, leaf firing, live green cover, normalized difference vegetation index, turf quality

SUMMARY. Turfgrass managers are using reclaimed water as an irrigation resource because of the decreasing availability and increasing cost of fresh water. Much attention, thereby, has been drawn to select salinity-tolerant turfgrass cultivars. An experiment was conducted to evaluate the relative salinity tolerance of $10 \mathrm{common}$ bermudagrasses (Cynodon dactylon) under a controlled environment in a randomized complete block design with six replications. 'SeaStar' seashore paspalum (Paspalum vaginatum) was included in this study as a salinity-tolerant standard. All entries were tested under four salinity levels $\left(1.5,15,30\right.$, and $\left.45 \mathrm{dS} \cdot \mathrm{m}^{-1}\right)$ consecutively using subirrigation systems. The relative salinity tolerance among entries was determined by various parameters, including the normalized difference vegetation index (NDVI), percentage green cover determined by digital image analysis (DIA), leaf firing (LF), turf quality (TQ), shoot vertical growth (VG), and dark green color index (DGCI). Results indicated that salinity tolerance varied among entries. Except LF, all parameters decreased as the salinity levels of the irrigation water increased. 'Princess 77 ' and 'Yukon' provided the highest level of performance among the common bermudagrass entries at the $30 \mathrm{dS} \cdot \mathrm{m}^{-1}$ salinity level. At $45 \mathrm{dS} \cdot \mathrm{m}^{-1}$, the percent green cover as measured using DIA varied from $4.97 \%$ to $16.11 \%$ among common bermudagrasses, where 'SeaStar' with a DIA of $\mathbf{2 2 . 9 2 \%}$ was higher than all the common bermudagrass entries. The parameters LF, TQ, NDVI, DGCI, VG, and DIA were all correlated with one another. Leaf firing had the highest correlation with other parameters, which defined its value as a relative salinity tolerance measurement for common bermudagrass development and selection.

$\mathrm{W}$ ater scarcity and the increasing cost of water favor warm-season grass over cool-season grass in the United States

Funds to support this research were provided by the Oklahoma Agricultural Experiment Station and the National Institute of Food and Agriculture, U.S. Department of Agriculture, under award number 2010-51181-21064.

We thank Paul Raymer for advice and guidance on the salinity testing methods, Bruce Dunn for providing the facility and technical help, and Kemin Su for the advice on taking the measurements. We also thank Carla Goad and Mike Smith for the advice on data analysis. In addition, we thank DLF International Seeds, Seed Research of Oregon, and Jacklin Seed by Simplot for donating the seeds to support this study.

This paper is a portion of a thesis submitted by Mingying Xiang in fulfilling the Oklahoma State University M.S. degree requirement.

${ }^{1}$ Department of Horticulture and Natural Resources, Kansas State University, Manhattan, KS 66502

${ }^{2}$ Department of Horticulture and Landscape Architecture, Oklahoma State University, Stillwater, OK 74078

${ }^{3}$ Department of Plant and Soil Sciences, Oklahoma State University, Stillwater, OK 74078

${ }^{4}$ Corresponding author. E-mail: justin.moss@okstate. edu.

https://doi.org/10.21273/HORTTECH03975-18 transition zone. Bermudagrass (Cynodon sp.), a warm-season, perennial grass, has been widely used in the southern United States for both forage and turf use (Wu and Anderson, 2011). Certain common bermudagrass cultivars are propagated by seed, whereas others are exclusively propagated by vegetative means because common bermudagrass is generally self-infertile and seed is not true-totype of the parent plant (Harlan and
De Wet, 1969). Certain seeded types have been increasingly used in the industry as they have comparable turfgrass quality and performance relative to interspecific hybrid bermudagrass (C. dactylon $\times$ Cynodon transvaalensis) at select use-sites (Patton et al., 2008).

Establishing a common bermudagrass sward by seeding costs less than solid sodding. Patton (2009) found that seeding costs were $\approx \$ 242$ / acre, whereas sprigging costs were $\approx \$ 1000 /$ acre and sodding was $\approx \$ 7500 /$ acre. The lower up-front establishment cost of common bermudagrass by seed makes it a desirable option for turfgrass managers, especially on projects with limited budgets.

In addition to cost concerns, many turfgrass production and reclamation sites across the United States are affected by soil salinity issues. The detrimental effects of salinity on grass growth include osmotic stress, specific ion toxicity, imbalances of nutrition, structural disorganization, and excessive energy resulting in damaged photosynthetic systems (Shahba et al., 2012). Saline-tolerant seeded-type common bermudagrass cultivars could produce acceptable quality turf in areas where reclaimed water is used for irrigation or soil salinity issues exist (Uddin et al., 2011). Information on the relative salinity tolerance of seedproducing common bermudagrass cultivars and experimental lines is, therefore, important for turfgrass industry professionals, breeders, and scientists.

Many objective and nondestructive evaluation parameters, such as NDVI, have been widely used in the turfgrass industry to evaluate TQ and monitor whether grasses are under stress. In particular, evaluating droughttolerant turfgrass by NDVI has been

\begin{tabular}{llll}
\hline $\begin{array}{l}\text { Units } \\
\begin{array}{l}\text { To convert U.S. to SI, } \\
\text { multiply by }\end{array}\end{array}$ & U.S. unit & SI unit & $\begin{array}{l}\text { To convert SI to U.S., } \\
\text { multiply by }\end{array}$ \\
\hline 0.4047 & acre $(\mathrm{s})$ & $\mathrm{ha}$ & 2.4711 \\
29.5735 & $\mathrm{fl} \mathrm{oz}$ & $\mathrm{mL}$ & 0.0338 \\
0.3048 & $\mathrm{ft}$ & $\mathrm{m}$ & 3.2808 \\
3.7854 & gal & $\mathrm{L}$ & 0.2642 \\
2.54 & inch $(\mathrm{es})$ & $\mathrm{cm}$ & 0.3937 \\
25.4 & inch $(\mathrm{es})$ & $\mathrm{mm}$ & 0.0394 \\
1.1209 & lb/acre & $\mathrm{kg} \cdot \mathrm{ha}^{-1}$ & 0.8922 \\
1 & $\mathrm{mmho} / \mathrm{cm}$ & $\mathrm{dS} \cdot \mathrm{m}^{-1}$ & 1 \\
28.3495 & $\mathrm{oz}$ & $\mathrm{g}$ & 0.0353 \\
7.4892 & $\mathrm{oz} / \mathrm{gal}$ & $\mathrm{g} \cdot \mathrm{L}^{-1}$ & 0.1335 \\
1 & $\mathrm{ppm}$ & $\mathrm{mg} \cdot \mathrm{L}^{-1}$ & 1 \\
$\left({ }^{\circ} \mathrm{F}-32\right) \div 1.8$ & ${ }^{\circ} \mathrm{F}$ & ${ }^{\circ} \mathrm{C}$ & $\left({ }^{\circ} \mathrm{C} \times 1.8\right)+32$ \\
\end{tabular}


well documented, but little has been found on salinity response (Xiang et al., 2017). In addition, new smartphone apps have recently been marketed for turf assessment, but extensive investigation regarding the effectiveness of these tools to evaluate grasses under salinity stress is needed. The objective of this research was to determine the relative salinity tolerance of seeded-type turf bermudagrasses, including seven industry standards and three Oklahoma State University (OSU) experimental lines using objective, nondestructive measurement parameters.

\section{Materials and methods}

Plant materials and growth CONDITIONs. Seven seeded-type common bermudagrass cultivars were selected as industry standards: Princess 77, NuMex Sahara, Pyramid 2 (DLF International Seeds, Roskilde, Denmark), Royal Bengal (Seed Research of Oregon, Tangent, OR), Southern Star (Jacklin Seed by Simplot, Liberty Lake, WA), Yukon (Seed Research of Oregon), and Riviera. These were selected because of their inclusion in national trials conducted by the National Turfgrass Evaluation Program (NTEP), including the 2007 and 2013 National Bermudagrass Tests (NTEP, 2007, 2013). In addition, three OSU experimental lines were included in this test: OKS 2009-3, OKS 2011-1, and OKS 2011-4. These latter three selections were included because of their improved cold tolerance (NTEP, 2016) and unknown salinity tolerance. 'NuMex Sahara' and 'Riviera' were included as the salinity-sensitive and salinitytolerant standards, respectively, based on previous findings (Marcum and Pessarakli, 2006). 'SeaStar' seashore paspalum, which is known as a salttolerant turfgrass (Schwartz et al., 2013), was also included as a standard.

Koch and Bonos (2011) reported that turfgrass salinity tolerance greenhouse data correlated well with turfgrass salinity tolerance field studies. Therefore, we used a controlled environment to decrease variability in salinity treatment and response affected by other factors. This experiment was conducted at the greenhouse facility in Stillwater, OK, from Jan. through Dec. 2014.
Air temperatures in the greenhouse recorded at $1.4 \mathrm{~m}$ above the concrete floor ranged between 25 and $37^{\circ} \mathrm{C}$ during the day and between 21 and $30{ }^{\circ} \mathrm{C}$ at night. Supplemental highpressure sodium light was provided from 0700 to $2100 \mathrm{HR}$ and brought daily maximum photosynthetically active radiation levels from 700 to $1150 \mathrm{~mol} \cdot \mathrm{m}^{-2} \cdot \mathrm{s}^{-1}$ at turfgrass canopy level.

Common bermudagrass entries were seeded into several individual greenhouse trays $(11 \times 21.5 \times 2.5$ inches) at $0.4-0.8 \mathrm{~g} /$ tray (equivalent to $24.4-43.4 \mathrm{~kg} \cdot \mathrm{ha}^{-1}$ ) pure live seed depending on coated or uncoated seed sources during Jan. 2014. Grasses were established under a mist system scheduled to water $10 \mathrm{~s}$ every 20 min until all entries reached uniform germinations. The grasses were established in sand meeting U.S. Golf Association (USGA) Topmix specifications (USGA Green Section Staff, 2004) mixed with gypsum at $3 \mathrm{~g} \cdot \mathrm{L}^{-1}$ of sand to minimize the effects of nutrient uptake of grasses under sodium chloride stress (Guimarães et al., 2012) and avoid deficiency of sulfur. Fertilizer was applied three times per week at $250 \mathrm{mg} \cdot \mathrm{L}^{-1}$ nitrogen $(\mathrm{N})$ using a solution of $20 \mathrm{~N}-8.6 \mathrm{P}-16.6 \mathrm{~K}+2 \mathrm{~B}+5 \mathrm{Cu}+10 \mathrm{Fe}+$ $5 \mathrm{Mn}+0.09 \mathrm{Mo}+5 \mathrm{Zn}$ general purpose fertilizer, where the $\mathrm{N}$ in the fertilizer was composed of $2.1 \%$ nitrate- $\mathrm{N}$ and $17.9 \%$ urea-N (JR Peters, Allentown, PA). 'SeaStar' was collected from the field nursery at the OSU Turfgrass Research Center and was propagated by rhizome during July 2014. Common bermudagrasses were transplanted on 15 Aug. 2014 at 10 seedlings/pot $(11.14 \times 11.14 \mathrm{~cm})$.

All pots were moved to separate ebb and flow benches after they were fully established and were acclimated for 10 weeks before exposure to salinity treatments. The pots were trimmed at a $5-\mathrm{cm}$ height for 10 weeks. During the acclimation period, daily subirrigation was applied to all the pots by solution tanks $(50 \mathrm{gal})$ that were fitted with a water pump and timer. The greenhouse nonpotable water source used in this study had a $\mathrm{pH}$ of 7.8 , an electrical conductivity (EC) level of $0.5 \mathrm{dS} \cdot \mathrm{m}^{-1}$, and a sodium adsorption ratio (SAR) of 1.6. Water-soluble $13 \mathrm{~N}-0.9 \mathrm{P}-$ $10.8 \mathrm{~K}+6 \mathrm{Ca}+3 \mathrm{Mg}$ fertilizer (Excel Plug and Breeding Plant Special;
ICL Fertilizers, St. Louis, MO) at $0.52 \mathrm{~g} \cdot \mathrm{L}^{-1}$ (with a level of $\mathrm{N}$, phosphorus, potassium, calcium, and magnesium at $68,23,189,90$, and $27 \mathrm{mg} \cdot \mathrm{L}^{-1}$, respectively), magnesium sulfate at $160 \mathrm{mg} \cdot \mathrm{L}^{-1}$ (with a level of magnesium of $18 \mathrm{mg} \cdot \mathrm{L}^{-1}$, and sulfur at $24 \mathrm{mg} \cdot \mathrm{L}^{-1}$ ) were added to all irrigation tanks. The nutrient irrigation was applied daily to all entries to provide a baseline of salinity level of $1.5 \mathrm{dS} \cdot \mathrm{m}^{-1}$.

Shoots were clipped at $5 \mathrm{~cm} \mathrm{l} \mathrm{d}$ before initiation of salinity treatment to provide uniform starting conditions (Marcum, 1999). In addition, multiple measurements were recorded before initiating salinity treatment: visual TQ and LF measured by a human evaluator; NDVI, by a handheld sensor [GSNDVI (GreenSeeker ${ }^{\circledR}$; Trimble Navigation, Sunnyvale, CA)] and by a handheld chlorophyll meter [FSNDVI (FieldScout $^{\circledR}$ CM 1000 NDVI Chlorophyll Meter; Spectrum Technologies, Aurora, IL)]; DGCI and visual rating (VR), by a smartphone app (FieldScout ${ }^{\circledR}$ GreenIndex+ Turf App, Spectrum Technologies); and DIA, by a digital single-lens reflex camera and the SigmaScan Pro 5 software (Systat Software, San Jose, CA) (Karcher and Richardson, 2005; Richardson, 2001).

SALINITY TREATMENTs. Four separate salinity level treatments (1.5, 15,30 , and $45 \mathrm{dS} \cdot \mathrm{m}^{-1}$ ) were applied subsequently in this study. Fertilizer was mixed into both the control and salinity treatment, as described previously, to reach a baseline EC of $1.5 \mathrm{dS} \cdot \mathrm{m}^{-1}$. On 29 Oct. 2014, after recoding the day 0 data on TQ, LF, GSNDVI, FSNDVI, DGCI, VR, and DIA for all pots, an Instant Ocean Synthetic Sea Salt mix (Aquarium System, Mentor, $\mathrm{OH}$ ) was gradually added to the salinity treatment tank to reach the designated salinity level. The salt treatment was increased by $5 \mathrm{dS} \cdot \mathrm{m}^{-1}$ daily to reduce the occurrence of acute salinity stress to the plants until salinity reached $15 \mathrm{dS} \cdot \mathrm{m}^{-1}$ total (Marcum and Pessarakli, 2006; Marcum et al., 2005; Xiang et al., 2017). After holding the treatment tank salinity level at $15 \mathrm{dS} \cdot \mathrm{m}^{-1}$ for l week, data on all parameters were collected from the pots of both the control and salinity treatments. Shoots were clipped, and the salt dosage was then increased by $5 \mathrm{dS} \cdot \mathrm{m}^{-1}$ daily until 
it reached $30 \mathrm{dS} \cdot \mathrm{m}^{-1}$. Salt solution was again held at $30 \mathrm{dS} \cdot \mathrm{m}^{-1}$ for 1 week and followed by rating, measuring, and clipping. This cycle was repeated one more time with $45 \mathrm{dS} \cdot \mathrm{m}^{-1}$. To avoid an accumulation of salt in the growth media due to evaporation, $300 \mathrm{~mL}$ of the appropriate salinity treatment irrigation solution were applied overhead to flush the pots in 5 -d intervals.

To monitor fertilizer levels, the control treatment EC was measured using a portable EC meter (HI 9033; Hanna Instruments, Carrollton, TX). When the EC of the control tank was below $0.5 \mathrm{dS} \cdot \mathrm{m}^{-1}$, the aforementioned fertilizer was added to the control and salinity treatment tanks at $0.27 \mathrm{~g} \cdot \mathrm{L}^{-1}$ to compensate for any loss over a $1 \mathrm{dS} \cdot \mathrm{m}^{-1} \mathrm{EC}$ level (Xiang et al., 2017). The EC levels in the tanks providing salinity treatment were measured daily and adjusted when necessary. The solutions were replaced every $10 \mathrm{~d}$ in both tanks to avoid changes in nutrient ion concentrations.

Parameters evaluated. Similar to Xiang et al. (2017), seven nondestructive parameters were evaluated during the experiment to assess the performance of common bermudagrass under each treatment. Briefly, TQ and LF were rated on a scale of 1 to 9 , with $\mathrm{TQ}=9$ being a dense, uniform, green turf and $\mathrm{LF}=9$ being no wilting and no firing and 1 being dead brown turf (Morris, 2007). The DIA was determined via SigmaScan Pro 5 software. The NDVI was recorded using both GSNDVI and FSNDVI. In addition, DGCI and VR were determined by the FieldScout ${ }^{\circledR}$ GreenIndex+ Turf App.

Instead of determining the shoot dry weight like in Xiang et al. (2017), the VG measured in this study followed the method developed by Bremer et al. (2006) after slight modifications. The canopy height was measured in millimeters by placing a lightweight circular piece of cardboard with the same diameter of the pot over the canopy, and four spots were evenly marked on the edge of cardboard. The cardboard was lightweight enough to avoid bending the canopy but rigid enough to hold its shape (Bremer et al., 2006). The cardboard was randomly placed on the canopy, and the height of the canopy was measured every $5 \mathrm{~d}$ right before mowing. The average daily vertical growth rates were calculated by dividing the number of days between mowing.

Relative growth $(\%)=$

$\frac{\text { VG of salinized treatment of a species }}{\text { VG of the control treatment of that species }} \times 100$.

For each cultivar, grass shoot growth response to salinity was determined by calculating the salinity level resulting in 25\% (VG25) and
$50 \%$ (VG50) shoot dry weight reduction as compared with the control (Marcum and Pessarakli, 2006). Immediately after the salinity treatment, recovery data were taken using the method described in Xiang et al. (2017). Briefly, after holding the pots at $45 \mathrm{dS} \cdot \mathrm{m}^{-1}$ for 1 week, all the pots were flushed overhead daily with the nonportable water $\left(\mathrm{EC}=0.5 \mathrm{dS} \cdot \mathrm{m}^{-1}\right)$ for a total of $7 \mathrm{~d}$. Thereafter, all the pots were subirrigated for 8 weeks.

EXPERIMENTAL DESIGN AND STATISTICAL ANALYSIS. A split-plot experiment was conducted with six replications with salinity treatment as the main plot factor and cultivar/entry as the subplot factor. Analysis of variance was performed and mean separation of all data were determined among entries using Fisher's protected least significant difference, both at the 0.05 significance level using SAS (version 9.4; SAS Institute, Cary, NC). Regression analysis of the VG data was performed using SAS. Analysis of variance of the recovery data was conducted and mean separation was performed using Tukey's procedure using SAS, both at the 0.05 significance level.

\section{Results}

There was variation in the level of LF among the entries while LF increased as salinity level increased (Table 1). Leaf firing ranged from 7.3 to 8.7 at $15 \mathrm{dS} \cdot \mathrm{m}^{-1}$, where 'Princess 77 '

Table 1. Effect of four salinity treatments on leaf firing (LF) and turf quality (TQ) of 10 common bermudagrasses and 'SeaStar' seashore paspalum.

\begin{tabular}{|c|c|c|c|c|c|c|c|c|}
\hline \multirow[b]{3}{*}{ Entry } & \multicolumn{8}{|c|}{ Human evaluator (visual rating $1-9$ ) } \\
\hline & \multicolumn{4}{|c|}{ LF $^{\mathbf{z}}$} & \multicolumn{4}{|c|}{$\mathrm{TQ}^{\mathrm{y}}$} \\
\hline & EC 1.5 & EC 15 & EC 30 & EC 45 & EC 1.5 & EC 15 & EC 30 & EC 45 \\
\hline Riviera & $9.0 \mathrm{a}$ & $8.5 \mathrm{ab}$ & $4.7 \mathrm{bc}$ & $2.8 \mathrm{~cd}$ & $7.7 \mathrm{~b}$ & $8.2 \mathrm{ab}$ & $4.7 \mathrm{abc}$ & $2.8 \mathrm{~cd}$ \\
\hline Yukon & $9.0 \mathrm{a}$ & $8.2 \mathrm{abc}$ & $5.0 \mathrm{ab}$ & $3.2 \mathrm{bc}$ & $8.5 \mathrm{a}$ & $8.0 \mathrm{abc}$ & $5.0 \mathrm{ab}$ & $3.2 \mathrm{bc}$ \\
\hline Pyramid 2 & $9.0 \mathrm{a}$ & 8.dbcd & $4.3 \mathrm{de}$ & $2.5 \mathrm{de}$ & $7.7 \mathrm{~b}$ & $7.8 \mathrm{bcd}$ & $4.3 \mathrm{~cd}$ & $2.5 \mathrm{de}$ \\
\hline NuMex Sahara & $9.0 \mathrm{a}$ & 7.7 cde & $3.8 \mathrm{f}$ & $2.0 \mathrm{f}$ & $7.0 \mathrm{~d}$ & $7.2 \mathrm{def}$ & $3.8 \mathrm{e}$ & $2.0 \mathrm{e}$ \\
\hline SeaStarv & $9.0 \mathrm{a}$ & $7.5 \mathrm{de}$ & $4.5 \mathrm{~cd}$ & $4.0 \mathrm{a}$ & $7.0 \mathrm{~d}$ & $6.8 \mathrm{f}$ & $4.5 \mathrm{bcd}$ & $4.0 \mathrm{a}$ \\
\hline Southern Star & $9.0 \mathrm{a}$ & $7.5 \mathrm{de}$ & $4.0 \mathrm{ef}$ & $2.2 \mathrm{ef}$ & $7.5 \mathrm{bc}$ & 7.0 ef & $4.0 \mathrm{de}$ & $2.2 \mathrm{e}$ \\
\hline OKS 2009-3 & $9.0 \mathrm{a}$ & $7.5 \mathrm{de}$ & $3.7 \mathrm{f}$ & $2.0 \mathrm{f}$ & $7.0 \mathrm{~d}$ & $7.2 \mathrm{def}$ & $3.7 \mathrm{e}$ & $2.0 \mathrm{e}$ \\
\hline OKS 2011-1 & $9.0 \mathrm{a}$ & $7.3 \mathrm{de}$ & $4.3 \mathrm{de}$ & $2.3 \mathrm{ef}$ & $7.0 \mathrm{~d}$ & $7.5 \mathrm{cde}$ & $4.3 \mathrm{~cd}$ & $2.3 \mathrm{de}$ \\
\hline
\end{tabular}

${ }^{\mathrm{z}} 1=$ total LF and $9=$ no LF.

${ }^{\mathrm{y}} 1=$ dead or dormant turf, $6=$ acceptable turf, and $9=$ excellent turf.

${ }^{\mathrm{x}}$ Data were collected for electrical conductivity (EC) 1.5 on day 0 , for EC 15 on day 10 , for EC 30 on day 20 , and EC 45 on day 30 of the experiment. After collecting the EC 1.5 data on day 0 , the salt concentration was increased by $5 \mathrm{dS} \cdot \mathrm{m}^{-1}$ daily until the $15 \mathrm{dS} \cdot \mathrm{m}^{-1}$ salinity level was reached and was held at $15 \mathrm{dS} \cdot \mathrm{m}^{-1}$ for 1 week. On day 10 , all data were collected for all entries for the EC 15 treatment level. This process was repeated for both the 30 and $45 \mathrm{dS} \cdot \mathrm{m}^{-1}$ treatment levels. In addition to the salinity treatment pots, a set of control pots was maintained at $1.5 \mathrm{dS} \cdot \mathrm{m}^{-1}$ throughout the study period; $1 \mathrm{dS} \cdot \mathrm{m}^{-1}=1 \mathrm{mmho} / \mathrm{cm}$.

${ }^{\mathrm{w}}$ Means accompanied by the same lowercase letter in the same column are not significantly different at the $P=0.05$ level $(n=6)$.

'SeaStar' seashore paspalum was included as high salinity-tolerant standard. 
had less LF than all other entries except 'Riviera' and 'Yukon'. Significant declines were found in all entries thereafter. At $30 \mathrm{dS} \cdot \mathrm{m}^{-1}$, less LF was displayed in 'Princess 77 ' than other entries with the exception of 'Yukon'. At $45 \mathrm{dS} \cdot \mathrm{m}^{-1}, \mathrm{LF}$ ranged from to 2.0 to 4.0 , and 'SeaStar' had the least LF. At $15 \mathrm{dS} \cdot \mathrm{m}^{-1}$, significant differences were only found in 'Southern Star', 'Yukon', and experimental entry OKS 2011-1, when comparing their performance with control treatment (Table 2). Overall, 'Princess 77' and 'Yukon' showed less LF at 15 and $30 \mathrm{dS} \cdot \mathrm{m}^{-1}$ , whereas 'SeaStar' displayed the least $\mathrm{LF}$ at $45 \mathrm{dS} \cdot \mathrm{m}^{-1}$.

Before initiating the salinity treatment, TQ ranged from 7.0 to 8.7 (Table 1), which demonstrates the inherent genetic differences among entries in terms of leaf texture and leaf color. At $15 \mathrm{dS} \cdot \mathrm{m}^{-1}$, all entries had acceptable TQ (TQ $\geq 6)$, and TQ was higher in 'Princess 77' compared with other entries, except 'Riviera' and 'Yukon'. Turf quality ranged from 3.7 to 5.2 at $30 \mathrm{dS} \cdot \mathrm{m}^{-1}$, and 'Princess 77' again displayed better TQ when compared with other entries besides 'Riviera' and 'Yukon'. At $45 \mathrm{dS} \cdot \mathrm{m}^{-1}$, TQ ranged from 2.0 to 4.0 , and 'SeaStar' had higher TQ than other entries, with the exception of 'Princess 77'. At $15 \mathrm{dS} \cdot \mathrm{m}^{-1}$, comparing all entries under salinity to the control treatment, a decline in TQ was found only in experimental entry OKS 2009-3 $(P=0.05)$, 'Southern Star' $(P=0.05)$, and 'Yukon' $(P=$ 0.01 ) (Table 2). Significant declines were found in all entries thereafter (data not shown).

Before salinity treatment, GSNDVI differed by entry and ranged from 0.757 to 0.848 (Table 3 ). Differences in GSNDVI between control and salinity treatment at $15 \mathrm{dS} \cdot \mathrm{m}^{-1}$ was found for 'Princess 77 ' $(P=0.05)$,
'Royal Bengal' $(P=0.05)$, 'Southern Star' $(P=0.05)$, 'Yukon' $(P=0.05)$, and experimental entry OKS 2009-3 $(P=0.01)$ (Table 2). Among the entries in the salinity treatment trial, the GSNDVI was highest in 'Yukon', 'Riviera', 'Princess 77', and 'Pyramid 2'. At $45 \mathrm{dS} \cdot \mathrm{m}^{-1}$, the GSNDVI of 'SeaStar' was the highest (Table 3 ).

Before salinity treatment, the FSNDVI ranged from 0.635 to 0.707 . The FSNDVI was higher for 'Princess 77' and 'Yukon' when compared with all other entries, except 'Riviera' and OKS 2011-4. A decline in FSNDVI was only found in 'NuMex Sahara', 'Southern Star', 'Yukon' 'Royal Bengal', 'Southern Star', and experimental entries OKS 2011-1, OKS 2009-3, and OKS 2011-4, when comparing the control vs. the entries at a $15 \mathrm{~d} \cdot \mathrm{m}^{-1}$ salinity treatment (Table 2). Values for FSNDVI at $30 \mathrm{dS} \cdot \mathrm{m}^{-1}$ were high for 'Princess 77' and 'Yukon' and

Table 2. Mean leaf firing (LF), turf quality (TQ), normalized difference vegetation index (NDVI), dark green color index (DGCI), and visual rating (VR) for 10 common bermudagrass and 'SeaStar' seashore paspalum under nonsalinity control and salinity treatment of $15 \mathrm{dS} \cdot \mathrm{m}^{-1}$.

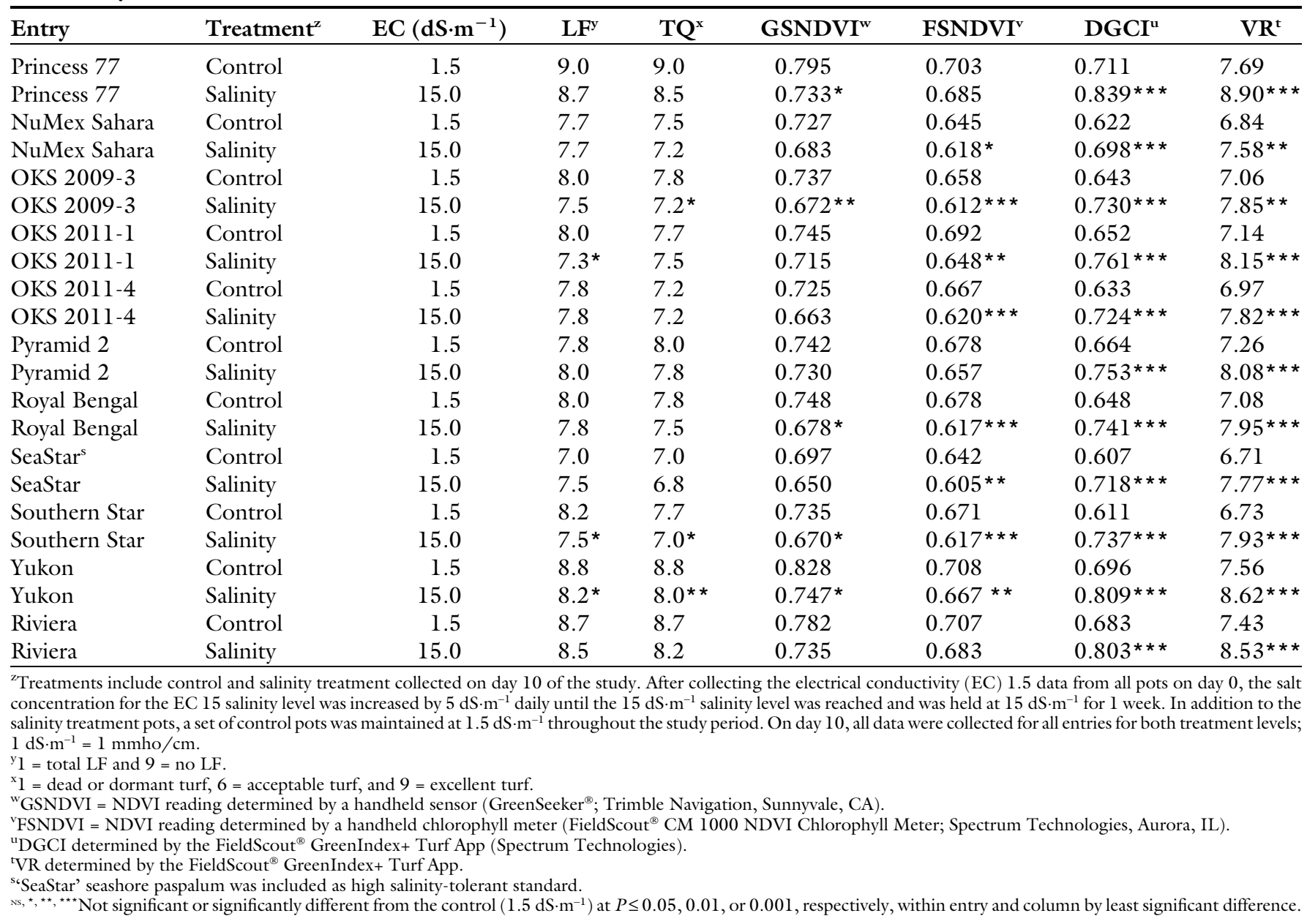


low for 'NuMex Sahara' and OKS 20093. At $45 \mathrm{dS} \cdot \mathrm{m}^{-1}$, 'SeaStar' had a higher FSNDVI than other entries, except for 'Princess 77' and 'Yukon' (Table 3).

The DGCI of 'Yukon' was higher compared with all entries, except for 'Princess 77' and 'Riviera', before initiating the salinity treatment (Table 4). As the salinity level increased to $15 \mathrm{dS} \cdot \mathrm{m}^{-1}$, all the entries showed significantly darker color under salinity stress when compared with the control $[P=0.001$ (Table 2)]. At $15 \mathrm{dS} \cdot \mathrm{m}^{-1}$, DGCI was higher for 'Princess 77' than all other entries, except 'Yukon' and 'Riviera'; it was lowest for 'NuMex Sahara'. At $45 \mathrm{dS} \cdot \mathrm{m}^{-1}$, DGCI was found higher in 'SeaStar' and 'Princess 77' compared with all other entries besides 'Yukon' (Table 4).

The calculation of VR on the smartphone application was based on DGCI data; therefore, the results were similar for both parameters (Tables 2 and 4). At $15 \mathrm{dS} \cdot \mathrm{m}^{-1}$, all the ratings of VR were above 7.6. Visual ratings ranged from 3.9 to 4.9 at $30 \mathrm{dS} \cdot \mathrm{m}^{-1}$. At $45 \mathrm{dS} \cdot \mathrm{m}^{-1}$, the VR was highest in 'SeaStar', 'Princess
77', and 'Yukon'. Though, 'Yukon' was statistically similar to the rest of the entries.

The DIA data, presented in Table 5, ranged from $85.7 \%$ to $98.7 \%$ before initiating salinity treatments. This analysis showed that percentage green cover was highest in 'Princess 77' and 'Yukon'. At $15 \mathrm{dS} \cdot \mathrm{m}^{-1}$, 'Princess 77' had higher DIA than all others besides 'Yukon' and 'SeaStar'. At $30 \mathrm{dS} \cdot \mathrm{m}^{-1}$, 'Princess 77', 'SeaStar', and 'Yukon' displayed higher DIA. The DIA was highest for the salinity standard 'SeaStar' at $45 \mathrm{dS} \cdot \mathrm{m}^{-1}$.

Table 3. Effect of four salinity treatments on the normalized difference vegetation index (NDVI) derived from two handheld instruments.

\begin{tabular}{|c|c|c|c|c|c|c|c|c|}
\hline \multirow[b]{3}{*}{ Entry } & \multicolumn{8}{|c|}{ NDVI $^{z}$} \\
\hline & \multicolumn{4}{|c|}{ GSNDVI $^{y}$} & \multicolumn{4}{|c|}{ FSNDVI $^{x}$} \\
\hline & EC 1.5 & EC 15 & EC 30 & EC 45 & EC 1.5 & EC 15 & EC 30 & EC 45 \\
\hline Riviera & $0.828 \mathrm{ab}$ & $0.735 \mathrm{a}$ & $0.665 \mathrm{abcd}$ & $0.272 \mathrm{bc}$ & $0.698 \mathrm{ab}$ & $0.683 \mathrm{a}$ & $0.499 \mathrm{bc}$ & $0.390 \mathrm{bc}$ \\
\hline Yukon & $0.845 \mathrm{a}$ & $0.747 \mathrm{a}$ & $0.690 \mathrm{a}$ & $0.302 \mathrm{~b}$ & $0.707 \mathrm{a}$ & $0.667 \mathrm{ab}$ & $0.541 \mathrm{a}$ & $0.407 \mathrm{ab}$ \\
\hline Pyramid 2 & $0.803 \mathrm{~b}$ & $0.730 \mathrm{ab}$ & 0.643 bcde & $0.232 \mathrm{~cd}$ & $0.677 \mathrm{bc}$ & $0.657 \mathrm{~b}$ & $0.502 \mathrm{~b}$ & $0.362 \mathrm{de}$ \\
\hline NuMex Sahara & $0.802 \mathrm{~b}$ & $0.683 \mathrm{bcd}$ & $0.563 \mathrm{~g}$ & $0.203 \mathrm{de}$ & $0.665 \mathrm{~cd}$ & $0.618 \mathrm{c}$ & $0.435 \mathrm{f}$ & $0.340 \mathrm{e}$ \\
\hline SeaStar ${ }^{\mathrm{v}}$ & $0.757 \mathrm{c}$ & $0.650 \mathrm{~d}$ & $0.668 \mathrm{abc}$ & $0.348 \mathrm{a}$ & $0.635 \mathrm{~d}$ & $0.605 \mathrm{c}$ & $0.492 \mathrm{bcd}$ & $0.428 \mathrm{a}$ \\
\hline Southern Star & $0.807 \mathrm{~b}$ & $0.670 \mathrm{~cd}$ & $0.625 \mathrm{def}$ & $0.187 \mathrm{e}$ & $0.665 \mathrm{c}$ & $0.617 \mathrm{c}$ & $0.465 \mathrm{e}$ & $0.348 \mathrm{de}$ \\
\hline OKS 2009-3 & $0.807 \mathrm{~b}$ & $0.672 \mathrm{~cd}$ & $0.592 \mathrm{fg}$ & $0.193 \mathrm{e}$ & $0.655 \mathrm{c}$ & $0.612 \mathrm{c}$ & $0.438 \mathrm{f}$ & $0.350 \mathrm{de}$ \\
\hline OKS 2011-1 & $0.805 \mathrm{~b}$ & $0.715 \mathrm{abc}$ & $0.683 \mathrm{ab}$ & $0.223 \mathrm{de}$ & $0.678 \mathrm{bc}$ & $0.648 \mathrm{~b}$ & $0.491 \mathrm{bcd}$ & $0.362 \mathrm{de}$ \\
\hline
\end{tabular}

${ }^{\mathrm{z}}$ Data were collected for electrical conductivity (EC) 1.5 on day 0 , for EC 15 on day 10 , for EC 30 on day 20 , and EC 45 on day 30 of the experiment. After collecting the EC 1.5 data on day 0 , the salt concentration was increased by $5 \mathrm{dS} \cdot \mathrm{m}^{-1}$ daily until the $15 \mathrm{dS} \cdot \mathrm{m}^{-1}$ salinity level was reached and was held at $15 \mathrm{dS} \cdot \mathrm{m}^{-1}$ for 1 week. On day 10 , all data were collected for all entries for the EC 15 treatment level. This process was repeated for both the 30 and $45 \mathrm{dS} \cdot \mathrm{m}^{-1}$ treatment levels. In addition to the salinity treatment pots, a set of control pots was maintained at $1.5 \mathrm{dS} \cdot \mathrm{m}^{-1}$ throughout the study period; $\mathrm{l} \mathrm{dS} \cdot \mathrm{m}^{-1}=1 \mathrm{mmho} / \mathrm{cm}$.

${ }^{y}$ FSNDVI = NDVI reading determined by a handheld chlorophyll meter (FieldScout ${ }^{\circledR}$ CM 1000 NDVI Chlorophyll Meter; Spectrum Technologies, Aurora, IL).

${ }^{\mathrm{x}}$ GSNDVI $=$ NDVI reading determined by a handheld sensor (GreenSeeker ${ }^{\circledR}$; Trimble Navigation, Sunnyvale, CA).

"Means accompanied by the same lowercase letter in the same column are not significantly different at the $P=0.05$ level $(n=6)$.

"SeaStar' seashore paspalum was included as high salinity-tolerant standard.

Table 4. Effect of four salinity treatments on dark green color index (DGCI) and visual rating (VR) of 10 common bermudagrasses and 'SeaStar' seashore paspalum as measured by smartphone app (FieldScout ${ }^{\circledR}$ GreenIndex + Turf App; Spectrum Technologies, Aurora, IL).

\begin{tabular}{|c|c|c|c|c|c|c|c|c|}
\hline \multirow[b]{2}{*}{ Entry } & \multicolumn{4}{|c|}{ DGCI } & \multicolumn{4}{|c|}{ VR } \\
\hline & $\mathrm{EC}^{\mathrm{z}} \mathbf{1 . 5}$ & EC 15 & EC 30 & EC 45 & EC 1.5 & EC 15 & EC 30 & EC 45 \\
\hline Princess 77 & $0.893 \mathrm{ab}^{\mathrm{y}}$ & $0.839 \mathrm{a}$ & $0.402 \mathrm{ab}$ & $0.351 \mathrm{a}$ & $9.4 \mathrm{a}$ & $8.9 \mathrm{a}$ & $4.8 \mathrm{ab}$ & $4.3 \mathrm{a}$ \\
\hline Yukon & $0.900 \mathrm{a}$ & $0.809 \mathrm{ab}$ & $0.410 \mathrm{a}$ & $0.320 \mathrm{ab}$ & $9.5 \mathrm{a}$ & $8.6 \mathrm{ab}$ & $4.9 \mathrm{a}$ & $4.0 \mathrm{ab}$ \\
\hline Pyramid 2 & $0.850 \mathrm{c}$ & $0.753 \mathrm{~cd}$ & $0.338 \mathrm{~cd}$ & $0.303 \mathrm{~b}$ & $9.0 \mathrm{~b}$ & $8.1 \mathrm{~cd}$ & $4.2 \mathrm{bcd}$ & $3.8 \mathrm{~b}$ \\
\hline OKS 2011-4 & $0.780 \mathrm{ef}$ & $0.724 \mathrm{~d}$ & $0.360 \mathrm{abcd}$ & $0.293 \mathrm{~b}$ & $8.3 \mathrm{de}$ & $7.8 \mathrm{de}$ & $4.4 \mathrm{abcd}$ & $3.8 \mathrm{~b}$ \\
\hline SeaStar ${ }^{x}$ & $0.750 \mathrm{f}$ & $0.718 \mathrm{~d}$ & $0.412 \mathrm{a}$ & $0.359 \mathrm{a}$ & $8.1 \mathrm{e}$ & $7.8 \mathrm{de}$ & $4.9 \mathrm{a}$ & $4.4 \mathrm{a}$ \\
\hline Southern Star & $0.780 \mathrm{ef}$ & $0.737 \mathrm{~d}$ & $0.376 \mathrm{abc}$ & $0.304 \mathrm{~b}$ & $8.3 \mathrm{de}$ & $7.9 \mathrm{de}$ & $4.5 \mathrm{abc}$ & $3.8 \mathrm{~b}$ \\
\hline OKS 2009-3 & $0.798 \mathrm{de}$ & $0.730 \mathrm{~d}$ & $0.320 \mathrm{~cd}$ & $0.298 \mathrm{~b}$ & $8.5 \mathrm{~cd}$ & $7.9 \mathrm{de}$ & $4.0 \mathrm{~cd}$ & $3.8 \mathrm{~b}$ \\
\hline OKS 2011-1 & $0.829 \mathrm{~cd}$ & $0.761 \mathrm{bcd}$ & $0.369 \mathrm{abcd}$ & $0.303 \mathrm{~b}$ & $8.8 \mathrm{bc}$ & $8.2 \mathrm{bcd}$ & $4.5 \mathrm{abcd}$ & $3.9 \mathrm{~b}$ \\
\hline
\end{tabular}

${ }^{\mathrm{z}}$ Data were collected for electrical conductivity (EC) 1.5 on day 0 , for EC 15 on day 10, for EC 30 on day 20 , and EC 45 on day 30 of the experiment. After collecting the EC 1.5 data on day 0 , the salt concentration was increased by $5 \mathrm{dS} \cdot \mathrm{m}^{-1}$ daily until the $15 \mathrm{dS} \cdot \mathrm{m}^{-1}$ salinity level was reached and was held at $15 \mathrm{dS} \cdot \mathrm{m}^{-1}$ for 1 week. On day 10 , all data were collected for all entries for the EC 15 treatment level. This process was repeated for both the 30 and $45 \mathrm{dS} \cdot \mathrm{m}^{-1}$ treatment levels; $1 \mathrm{dS} \cdot \mathrm{m}^{-1}=1 \mathrm{mmho} / \mathrm{cm}$.

${ }^{y}$ Means accompanied by the same lowercase letter in the same column are not significantly different at the $P=0.05$ level $(n=6)$.

‘'SeaStar' seashore paspalum was included as high salinity-tolerant standard. 
Linear and cubic trends were detected in 'Princess 77', 'Riviera', 'Pyramid 2', OKS 2011-4, 'NuMex Sahara', and OKS 2009-3, which indicate a more rapid decline in green cover when under higher salinity conditions.

The VG was measured by comparing treated with control entries for relative VG. The relative vertical growth declined linearly $\left(R^{2}>0.88\right)$ with increasing salinity (Table 6). Regression analysis shows that 25\% relative (to control) shoot vertical growth reduction (VG25) ranged from 10.9 to $11.8 \mathrm{dS} \cdot \mathrm{m}^{-1}$ for common bermudagrass entries (Table 6 ). 'SeaStar' had the VG50 at the highest salinity level of $23 \mathrm{dS} \cdot \mathrm{m}^{-1}$. Based on the data trend, the rank of these common bermudagrass entry according to the salinity level for VG50 was as follows: 'Yukon' $>$ 'Princess 77' > OKS 2009-3 > 'Southern Star' > OKS 2011-4 > OKS 2011-1 > 'Royal Bengal' > 'Pyramid 2' > 'Riviera' > 'NuMex Sahara'.

All parameters (LF, TQ, FSNDVI, GSNDVI, DGCI, VR, DIA, and VG)

Table 5. Effect of four salinity treatments and trend analysis on live green cover of 10 common bermudagrasses and 'SeaStar' seashore paspalum assessed through digital image analysis (DIA).

\begin{tabular}{llllll}
\hline & \multicolumn{5}{c}{ Live green cover $(\%)^{\mathrm{z}}$} \\
\cline { 2 - 5 } Entry & EC 1.5 & EC 15 & EC 30 & EC 45 & Significance \\
\hline Princess 77 & $98.7 \mathrm{a}^{\mathrm{x}}$ & $91.0 \mathrm{a}$ & $57.1 \mathrm{a}$ & $16.1 \mathrm{~b}$ & $\mathrm{~L}^{* * *} \mathrm{C}^{*}$ \\
Riviera & $92.6 \mathrm{bc}$ & $85.0 \mathrm{bc}$ & $39.4 \mathrm{bc}$ & $11.8 \mathrm{bcd}$ & $\mathrm{L}^{* * *} \mathrm{C}^{* * *}$ \\
Yukon & $98.2 \mathrm{a}$ & $89.1 \mathrm{ab}$ & $54.0 \mathrm{a}$ & $14.6 \mathrm{bc}$ & $\mathrm{L}^{* *}$ \\
Pyramid 2 & $92.5 \mathrm{c}$ & $79.8 \mathrm{~cd}$ & $40.0 \mathrm{bc}$ & $10.3 \mathrm{bcd}$ & $\mathrm{L}^{* *} \mathrm{C}^{* *}$ \\
OKS 2011-4 & $85.7 \mathrm{~d}$ & $72.1 \mathrm{e}$ & $25.2 \mathrm{c}$ & $5.0 \mathrm{~d}$ & $\mathrm{~L}^{* * *} \mathrm{C}^{* * *}$ \\
Royal Bengal & $86.7 \mathrm{~d}$ & $71.6 \mathrm{e}$ & $41.3 \mathrm{bc}$ & $7.7 \mathrm{bcd}$ & $\mathrm{L}^{* *}$ \\
NuMex Sahara & $95.5 \mathrm{~b}$ & $78.4 \mathrm{de}$ & $35.9 \mathrm{bc}$ & $4.6 \mathrm{~d}$ & $\mathrm{~L}^{* *} \mathrm{C}^{* * *}$ \\
SeaStarw & $91.7 \mathrm{c}$ & $85.8 \mathrm{ab}$ & $57.4 \mathrm{a}$ & $22.9 \mathrm{a}$ & $\mathrm{L}^{* * *}$ \\
Southern Star & $93.1 \mathrm{bc}$ & $71.7 \mathrm{e}$ & $38.0 \mathrm{bc}$ & $6.9 \mathrm{bcd}$ & $\mathrm{L}^{* * *}$ \\
OKS 2009-3 & $87.1 \mathrm{~d}$ & $72.3 \mathrm{e}$ & $35.0 \mathrm{c}$ & $6.6 \mathrm{~d}$ & $\mathrm{~L}^{* * *} \mathrm{C}^{* *}$ \\
OKS 2011-1 & $90.4 \mathrm{~cd}$ & $78.6 \mathrm{de}$ & $44.8 \mathrm{~b}$ & $10.0 \mathrm{bcd}$ & $\mathrm{L}^{* * *}$ \\
\hline
\end{tabular}

${ }^{\mathrm{z}}$ Live green coverage percent is the DIA as a percentage determined by SigmaScan software (Systat Software, San Jose, CA). The least significant difference grouping was presented after arcsin transformation.

${ }^{y}$ Data were collected for electrical conductivity (EC) 1.5 on day 0 , for EC 15 on day 10 , for EC 30 on day 20, and EC 45 on day 30 of the experiment. After collecting the EC 1.5 data on day 0 , the salt concentration was increased by $5 \mathrm{dS} \cdot \mathrm{m}^{-1}$ daily until the $15 \mathrm{dS} \cdot \mathrm{m}^{-1}$ salinity level was reached and was held at $15 \mathrm{dS} \cdot \mathrm{m}^{-1}$ for 1 week. On day 10 , all data were collected for all entries for the EC 15 treatment level. This process was repeated for both the 30 and $45 \mathrm{dS} \cdot \mathrm{m}^{-1}$ treatment levels; $1 \mathrm{dS} \cdot \mathrm{m}^{-1}=1 \mathrm{mmho} / \mathrm{cm}$.

${ }^{x}$ Means accompanied by the same lowercase letter in the same column are not significantly different at the $P=0.05$ level $(n=6)$.

"'SeaStar' seashore paspalum was included as high salinity-tolerant standard.

${ }^{*},{ }^{*}, * * *$ Significant linear $(\mathrm{L})$, quadratic $(\mathrm{Q})$, or cubic $(\mathrm{C})$ trend at $P=0.05,0.01$, and 0.001 , respectively, by Fisher's F test. were highly positively correlated with one another $[r>0.71, P<0.001$ (Table 7)]. Leaf firing had the highest correlation coefficient with all other parameters measured and ranked as the best factor in evaluating common bermudagrass under salinity stress. When comparing all the sensors and the smartphone application, FSNDVI showed a higher correlation compared with GSNDVI and DGCI/VR in this study. As a physiological factor, VG was similar to the other parameters based on correlation.

Recovery is an indirect method of evaluating salinity tolerance. If a cultivar requires a shorter recovery period, it may have a better growth vigor. The live green cover varied among entries (Table 8). A linear, quadratic, and cubic trend was detected in 'Riviera', which demonstrates its ability to recover from 2 to 4 weeks after beginning the recovery period. At week 8 , the live green cover of the common bermudagrass entries ranged from $26.1 \%$ to $73.5 \%$, where 'SeaStar' had a cover of $71.1 \%$.

\section{Discussion}

It is evident that a diversity of salinity tolerance existed among common bermudagrass industry standards and OSU experimental lines. Differences among the 10 common bermudagrass entries were demonstrated based on the ranking of all parameters except VG. The entries were ranked in order from the most salinity tolerant to the least: 'Princess 77', 'Yukon', 'Riviera', OKS 2011-1, OKS 2011-4, 'Southern

Table 6. Predicted salinity level for $\mathbf{2 5 \%}$ vertical shoot growth reduction (VG 25 ) and $\mathbf{5 0} \%$ vertical shoot growth reduction (VG50) of 10 common bermudagrasses and 'SeaStar' seashore paspalum.

\begin{tabular}{|c|c|c|c|c|}
\hline \multirow[b]{2}{*}{ Entry } & \multirow[b]{2}{*}{ Regression of relative shoot growth under different stress } & \multirow[b]{2}{*}{$r^{2 \mathrm{z}}$} & \multicolumn{2}{|c|}{ Predicted salinity level $\left(\mathrm{dS} \cdot \mathrm{m}^{-1}\right)^{\mathrm{y}}$} \\
\hline & & & VG25 & VG50 \\
\hline Princess 77 & $y=-0.0226 x+1.012$ & 0.92 & 11.2 & 22.4 \\
\hline Yukon & $y=-0.0226 x+1.0165$ & 0.90 & 11.2 & 22.5 \\
\hline Pyramid 2 & $y=-0.0201 x+0.88$ & 0.88 & 11.0 & 21.9 \\
\hline OKS 2011-4 & $\mathrm{y}=-0.024 \mathrm{x}+1.0633$ & 0.92 & 11.1 & 22.2 \\
\hline SeaStar & $y=-0.0215 x+0.9906$ & 0.90 & 11.5 & 23.0 \\
\hline Southern Star & $y=-0.0222 x+0.9884$ & 0.89 & 11.1 & 22.3 \\
\hline OKS 2009-3 & $y=-0.0219 x+0.9788$ & 0.89 & 11.2 & 22.3 \\
\hline OKS 2011-1 & $\mathrm{y}=-0.0226 \mathrm{x}+0.9938$ & 0.91 & 11.0 & 22.1 \\
\hline
\end{tabular}

${ }^{\mathrm{z}} \gamma^{2}$ is the coefficient of determination, and the larger value indicates the better perdition from the regression.

${ }^{\mathrm{y}} \mathrm{l} \mathrm{dS} \cdot \mathrm{m}^{-1}=1 \mathrm{mmho} / \mathrm{cm}$.

‘'SeaStar' seashore paspalum was included as high salinity-tolerant standard. 
Table 7. Pearson correlation coefficient for leaf firing (LF), turf quality (TQ), normalized difference vegetation index (NDVI), dark green color index (DGCI), visual rating (VR), vertical shoot growth (VG), and digital image analysis (DIA).

\begin{tabular}{|c|c|c|c|c|c|c|c|c|}
\hline Parameter & $\mathbf{L F}^{\mathbf{z}}$ & $T_{Q}$ & FSNDVI $^{\mathrm{x}}$ & GSNDVI $^{\mathrm{w}}$ & DGCI $^{\mathbf{v}}$ & $\mathrm{VR}^{\mathbf{u}}$ & VG & DIA $^{t}$ \\
\hline LF & 1 & $0.932 * * *$ & $0.951 * * *$ & $0.894 * * *$ & $0.856 * * *$ & 0.856 *** & $0.869 * * *$ & $0.929 * *$ * \\
\hline TQ & & 1 & $0.942 * * *$ & $0.866 * * *$ & $0.845 * * *$ & $0.845^{* * *}$ & $0.832 * * *$ & $0.928 * *$ * \\
\hline FSNDVI & & & 1 & $0.899 * * *$ & $0.823 * * *$ & $0.824 * * *$ & $0.845^{* * *}$ & $0.928 * * *$ \\
\hline GSNDVI & & & & 1 & $0.741 * * *$ & $0.742 * * *$ & $0.718 * * *$ & $0.886 * * *$ \\
\hline DGCI & & & & & 1 & 1 & $0.776^{* * *}$ & $0.836 * * *$ \\
\hline VR & & & & & & 1 & $0.776^{* * *}$ & $0.837 * *$ * \\
\hline
\end{tabular}

${ }^{\mathrm{z}} \mathrm{LF}$ rated on the scale of $\mathrm{l}$ to 9 , where $\mathrm{l}=$ total $\mathrm{LF}$ and $9=$ no LF.

${ }^{\mathrm{y}} \mathrm{TQ}$ rated on the scale of 1 to 9 , where $1=$ dead or dormant turf, $6=$ acceptable turf, and $9=$ excellent turf.

${ }^{x}$ FSNDVI = NDVI reading determined by a handheld chlorophyll meter (FieldScout ${ }^{\otimes}$ CM 1000 NDVI Chlorophyll Meter; Spectrum Technologies, Aurora, IL).

${ }^{\mathrm{w}}$ GSNDVI = NDVI reading determined by a handheld sensor $\left(\right.$ GreenSeeker ${ }^{\circledR}$; Trimble Navigation, Sunnyvale, CA).

${ }^{v}$ DGCI determined by a smartphone app (FieldScout ${ }^{\circledR}$ GreenIndex+ Turf App, Spectrum Technologies).

"VR determined by a smartphone app (FieldScout ${ }^{\circledR}$ GreenIndex+ Turf App).

'DIA determined by SigmaScan software (Systat Software, San Jose, CA).

***Indicates significant of correlations at $P=0.001$.

Table 8. Recovery results after salinity treatment and trend analysis on live green cover of 10 common bermudagrasses and 'SeaStar' seashore paspalum assessed through digital image analysis (DIA) for an 8-week period.

\begin{tabular}{|c|c|c|c|c|c|}
\hline \multirow[b]{2}{*}{ Entry } & \multicolumn{4}{|c|}{ Live green cover $(\%)^{\mathrm{z}}$} & \multirow[b]{2}{*}{ Significance } \\
\hline & 0 wk & $2 \mathrm{wk}$ & $4 \mathrm{wk}$ & 8 wk & \\
\hline Princess 77 & $16.1 \mathrm{~b}^{\mathrm{y}}$ & $25.7 \mathrm{~b}$ & $44.7 \mathrm{~b}$ & $57.3 \mathrm{abc}$ & $\mathrm{L}^{\star * *}$ \\
\hline Riviera & $11.8 \mathrm{bcd}$ & $36.7 \mathrm{ab}$ & $70.2 \mathrm{a}$ & $73.5 \mathrm{a}$ & $\mathrm{L}^{* * *} \mathrm{Q}^{* *} \mathrm{C}^{*}$ \\
\hline Yukon & $14.6 \mathrm{bc}$ & $27.4 \mathrm{ab}$ & $41.2 \mathrm{bc}$ & $49.2 \mathrm{abcd}$ & $\mathrm{L}^{*}$ \\
\hline Pyramid 2 & $10.3 \mathrm{bcd}$ & $28.3 \mathrm{ab}$ & $46.2 \mathrm{~b}$ & $68.3 \mathrm{ab}$ & NS \\
\hline OKS 2011-4 & $5.0 \mathrm{~d}$ & $12.2 \mathrm{c}$ & $25.5 \mathrm{bcd}$ & $49.5 \mathrm{abcd}$ & $\mathrm{L}^{\star * *}$ \\
\hline Royal Bengal & $7.7 \mathrm{bcd}$ & $7.4 \mathrm{c}$ & $21.3 \mathrm{~cd}$ & $31.7 \mathrm{~cd}$ & $\mathrm{~L}^{*}$ \\
\hline NuMex Sahara & $4.6 \mathrm{~d}$ & $12.1 \mathrm{c}$ & $18.5 \mathrm{~d}$ & $31.2 \mathrm{~cd}$ & $\mathrm{~L}^{*}$ \\
\hline SeaStar ${ }^{x}$ & $22.9 \mathrm{a}$ & $38.7 \mathrm{a}$ & $41.3 \mathrm{bc}$ & $71.1 \mathrm{a}$ & $\mathrm{L}^{* * *} \mathrm{C}^{* *}$ \\
\hline Southern Star & $6.9 \mathrm{bcd}$ & $8.2 \mathrm{c}$ & $17.9 \mathrm{~d}$ & $35.9 \mathrm{~cd}$ & $\mathrm{~L}^{* *}$ \\
\hline OKS 2009-3 & $6.6 \mathrm{~d}$ & $7.6 \mathrm{c}$ & $21.2 \mathrm{~cd}$ & $45.3 \mathrm{bcd}$ & $\mathrm{L}^{* * *}$ \\
\hline OKS 2011-1 & $10.0 \mathrm{bcd}$ & $7.9 \mathrm{c}$ & $15.9 \mathrm{~d}$ & $26.1 \mathrm{~d}$ & NS \\
\hline
\end{tabular}

${ }^{\mathrm{z}}$ Live green cover is the DIA as a percentage determined by SigmaScan software (Systat Software, San Jose, CA), least significant difference grouping was presented after arcsin transformation.

${ }^{y}$ Means accompanied by the same lowercase letter in the same column are not significantly different at the $P=0.05$ level $(n=6)$.

'SeaStar' seashore paspalum was included as high salinity-tolerant standard.

${ }^{*},{ }^{* *},{ }^{* *}$ Significant linear $(\mathrm{L})$, quadratic $(\mathrm{Q})$, or cubic $(\mathrm{C})$ trend at $P=0.05,0.01$, and 0.001 , respectively, by Fisher's F test.

Star', 'Pyramid 2', 'Royal Bengal', OKS 2009-3, and 'NuMex Sahara' (Table 9). 'Princess77', 'Yukon', and 'Riviera' showed better salinity tolerance under most levels of salinity stress. At $45 \mathrm{~d} \cdot \mathrm{m}^{-1}$, 'SeaStar' seashore paspalum performed better than all common bermudagrasses. The readings of FSNDVI, GSNDVI, and DGCI/VR differ between species because of differences in turfgrass quality, as affected by leaf texture and leaf color, which might explain why 'SeaStar' ranked not as high as some of the common bermudagrass entries at 1.5 and $15 \mathrm{dS} \cdot \mathrm{m}^{-1}$.

Acceptable LF and TQ were detected for all the entries at 15 $\mathrm{d} S \cdot \mathrm{m}^{-1}$. Differences on LF and TQ between control and salinity of 15 $\mathrm{dS} \cdot \mathrm{m}^{-1}$ were only detected on the experimental selections. A minor decline in percentage cover was detected in all the entries when exposed to $15 \mathrm{dS} \cdot \mathrm{m}^{-1}$; severe declines were found thereafter. Although for a relatively brief duration, the common bermudagrasses tested in this study may manage effectively in moderately low salinity levels (below $\left.15 \mathrm{dS} \cdot \mathrm{m}^{-1}\right)$. Darker green color has been noticed across the common bermudagrasses at $15 \mathrm{dS} \cdot \mathrm{m}^{-1}$, which is comparable with the early symptoms of bermudagrass under drought stress.

Marcum and Pessarakli (2006) reported that 'Riviera' is relatively more salinity tolerant than 'Yukon' at $60 \mathrm{dS} \cdot \mathrm{m}^{-1}$, having a green leaf canopy area of $20 \%$ and $18 \%$, respectively. However, this study shows that 'Yukon' performed slightly better than 'Riviera'. This can be explained by the genetic diversity that exists in every single seedling for any seedpropagated common bermudagrass. To better represent a seeded entry in this study, 10 individual seedlings from each entry were transplanted into each pot; i.e., a total of 60 individual plants representing each released or experimental entry.

Leaf firing, compared with all other parameters, had a higher correlation with other parameters. These results agreed with the study of Xiang et al. (2017). We, therefore, recommend LF as the most important criterion when evaluating salinity tolerance in common bermudagrass cultivars. In addition, to ensure that consistent ratings are achieved, scientists should be well trained before the evaluation process and have the study rated by the same evaluators. Among the sensor-based parameters and smartphone app, FSNDVI had better accuracy than GSNDVI, and DGCI/VR. Considering the variations created by the environment, random errors can be minimized by comparing the control with the salinity treatment of each entry each day. FSNDVI has a very small field of view and is very simple to use, making it a very good parameter for the turfgrass greenhouse salinity study. Compared with the FSNDVI, GSNDVI has a larger field of view, which may be a factor that limits its accuracy for the greenhouse study. To narrow the measuring area 
Table 9. Rank of salinity tolerance of 10 common bermudagrasses and 'SeaStar' seashore paspalum.

\begin{tabular}{lcc}
\hline Entry & $\begin{array}{c}\text { Times in top statistical } \\
\text { group (no.) }\end{array}$ & $\begin{array}{c}\text { Times in bottom statistical } \\
\text { group (no.) }\end{array}$ \\
\hline Princess 77 & 25 & 0 \\
Yukon & 24 & 2 \\
Riviera & 15 & 6 \\
SeaStar & 13 & 10 \\
OKS 2011-1 & 5 & 14 \\
OKS 2011-4 & 4 & 21 \\
Southern Star & 3 & 18 \\
Pyramid 2 & 2 & 8 \\
Royal Bengal & 2 & 17 \\
OKS 2009-3 & 1 & 22 \\
NuMex Sahara & 1 & 24 \\
\hline
\end{tabular}

${ }^{z}$ Number of times of 28 total that the entry's mean ranked in the top or bottom statistical ranking group (according to Fisher's least significant difference at $P=0.05$ ) for the categories with a significant $\mathrm{F}$ test. These include leaf firing, turf quality, normalized difference vegetation index (NDVI) determined by handheld sensor [GSNDVI (GreenSeeker ${ }^{\circledR}$; Trimble Navigation, Sunnyvale, CA)], NDVI determined by a handheld chlorophyll meter [FSNDVI (FieldScout ${ }^{\circledR}$ CM 1000 NDVI Chlorophyll Meter; Spectrum Technologies, Aurora, IL)], dark green color index, visual rating, and digital image analysis determined by a smartphone app (FieldScout ${ }^{\circledR}$ GreenIndex+ Turf App, Spectrum Technologies).

${ }^{y}$ SeaStar seashore paspalum was included as high salinity-tolerant standard.

of the GSNDVI, a special black hood was attached to the bottom of the sensor to match with the diode viewing window. In addition, a black funnel was connected on top of the greenhouse pot to build a narrower field of view and, therefore, to avoid the background noise. For the FieldScout ${ }^{\circledR}$ GreenIndex+ Turf App, even though white balance was adjusted, results can be improved by controlled light conditions, such as with a light box.

Results showed that a narrow range was detected in the salinity levels leading to VG25 and VG50. Shoot vertical growth rate, compared with the other parameters, shows similar results with some exceptions. Grass with high relative shoot growth, less LF, and better TQ should be expected. However, at $30 \mathrm{dS} \cdot \mathrm{m}^{-1}$, the experimental entry OKS 2011-4 had $15.97 \%$ relative $\mathrm{VG}$ with a $3.7 \mathrm{LF}$ rating, whereas 'Yukon' had a 5.0 LF rating and $\mathrm{VG}$ of $13.98 \%$. These issues indicate that complicated mechanisms may be present in the salinity tolerance of bermudagrass.

\section{Literature cited}

Bremer, D.J., K. Su, S.J. Keeley, and J.D. Fry. 2006. Performance in the transition zone of two hybrid bluegrasses compared with Kentucky bluegrass and tall fescue. Appl. Turfgrass Sci. doi: 10. 1094/ATS2006-0808-02-RS.
Guimarães, F.V.A., C.F. Lacerda, E.C. Marques, C.E.B. Abreu, B.F. Aquino, J. T. Prisco, and E. Gomes-Filho. 2012. Supplemental $\mathrm{Ca}^{2+}$ does not improve growth but it affects nutrient uptake in NaCl-stressed cowpea plants. Braz. J. Plant Physiol. 24:9-18.

Harlan, J.R. and J.M.J. De Wet. 1969. Sources of variation in Cynodon dactylon (L). Pers. Crop Sci. 9:774-778.

Karcher, D.E. and M.D. Richardson. 2005. Batch analysis of digital images to evaluate turfgrass characteristics. Crop Sci. 45:1536-1539.

Koch, M.J. and S.A. Bonos. 2011. Salinity tolerance of cool-season turfgrass cultivars under field conditions. Appl. Turfgrass Sci. 8.

Marcum, K.B. 1999. Salinity tolerance mechanisms of grasses in the subfamily chlorideae. Crop Sci. 31:1153-1160.

Marcum, K.B. and M. Pessarakli. 2006. Salinity tolerance and salt gland excretion efficiency of bermudagrass turf cultivars. Crop Sci. 46:2571-2574.

Marcum, K.B., M. Pessarakli, and D. Kopec. 2005. Relative salinity tolerance of 21 turf-type desert saltgrasses compared to bermudagrass. HortScience 40:827-829.

Morris, K.N. 2007. A guide to NTEP turfgrass ratings. 20 Dec. 2017 . <http:// www.ntep.org/reports/ratings.htm>.

National Turfgrass Evaluation Program. 2007. The 2007 National Bermudagrass Test: Entries and sponsors. National Turfgrass Evaluation Program, Beltsville, MD.
National Turfgrass Evaluation Program. 2013. The 2013 National Bermudagrass Test: Entries and sponsors. National Turfgrass Evaluation Program, Beltsville, MD.

National Turfgrass Evaluation Program. 2016. The 2013 National Bermudagrass Test: Spring greeningup of bermudagrass (seeded) cultivars. National Turfgrass Evaluation Program, Beltsville, MD.

Patton, A. 2009. Establishing seeded bermudagrass on lawns, golf courses or athletic fields. 20 Dec. 2017. <https:// www.uaex.edu/publications /pdf/ MP477.pdf>.

Patton, A.J., M.D. Richardson, D.E. Karcher, J.W. Boyd, Z.J. Reicher, D.J. Fry, J.S. McElroy, and C.M. Gregg. 2008. A guide to establishing seeded bermudagrass in the transition zone. Appl. Turfgrass Sci. doi: 10.1094/ATS-20080122-01-MD.

Richardson, M.D. 2001. Quantifying turfgrass cover using digital image analysis. Crop Sci. 41:1884-1888.

Schwartz, B.M., R.N. Conteras, K.R. Harris-Shultz, D.L. Heckart, J.B. Peake, and P.L. Raymer. 2013. Discovery and characterization of a turf-type triploid seashore paspalum. HortScience 48: 1424-1427.

Shahba, M.A., S.F. Alshammary, and M. Abbas. 2012. Effects of salinity on seashore paspalum cultivars at different mowing heights. Crop Sci. 52:1358-1370.

Uddin, M.K., A.S. Juraimi, M.R. Isnail, M.R. Ismail, R. Othman, and A.A. Rahim. 2011. Relative salinity tolerance of warm season turfgrass species. J. Environ. Biol. 32:309-312.

USGA Green Section Staff. 2004. USGA recommendations for a method of putting green construction. 20 Dec. 2017. <https://www.usga.org/content/dam/ usga/images / course-care / $2004 \%$ 20USGA\%20Recommendations $\% 20$ For $\% 20$ a $\% 20$ Method $\% 20$ of $\% 20$ Putting\% 20Green\%20Cons.pdf>.

Wu, Y.Q. and J.A. Anderson. 2011. Genetic improvement of cold hardiness in bermudagrass, p. 851-852. In: $M$. Pessarakli (ed.). Handbook of plant and crop stress. CRC Press, New York, NY.

Xiang, M., J.Q. Moss, D.L. Martin, K. Su, B.L. Dunn, and Y. Wu. 2017. Evaluating the salinity tolerance of clonal-type bermudagrass cultivars and an experimental selection. HortScience 52:185-191. 